UDC 621.039.74

V. Kovalchuk, PhD, Assoc. Prof.,

I. Kozlov, DSc, Prof.,

O. Dorozh, PhD, Assoc. Prof.,

O. Siedova

Odessa National Polytechnic University, 1 Shevchenko Ave., Odessa, Ukraine, 65044; e-mail: odorog13@gmail.com

\title{
ASSESSMENT OF THE RELIABILITY OF THE NPP LIQUID RADIOACTIVE WASTE CONCENTRATION SYSTEM
}

\begin{abstract}
В.І. Ковальчук, І.Л. Козлов, О.А. Дорож, О.О. Сєдова .Оцінки надійності системи концентрування рідких радіоактивних відходів АЕС. Викладено розрахунок показників надійності системи концентрування рідких радіоактивних відходів АЕС. В якості базової схеми прийнята спецводоочистка трапних вод (СВО-3) блоків з реакторами ВВЕР. Метою роботи є розрахункова оцінка надійності СВО-3 як технологічної системи. Мета досягається шляхом перетворення технологічної схеми системи в структурну і визначення кількісних значень параметра потоку відмов, тривалості та ймовірності безвідмовної роботи. Побудовано структурну модель системи з урахуванням резервування та навішених елементів. Розглянуто характерні способи з'єднання елементів в системі: послідовне, одно- і дворазове постійне резервування, за однакових умов навантаження основного і резервного елементів $\mathrm{i}$ виконання тих самих функцій. Дані про параметри потоку відмов обладнання, що становить технологічну схему, запозичені 3 довідкових джерел. Присутні в схемі засоби комунікації (вентилі, фланці, трубопроводи тощо) враховані як приєднані послідовні елементи основного обладнання. Обчислені ймовірності безвідмовної роботи обладнання і виділені найбільш проблемні: насоси, випарники і теплообмінники. Визначено ймовірності безвідмовної роботи системи в цілому для ряду заданих проміжків експлуатації як відповідні добутки ймовірності безвідмовної роботи елементів, що складають систему. Показано, що при незмінності параметра потоку відмов, ймовірність безвідмовної роботи системи, що забезпечує ії ефективне функціонування, збережеться в межах одного року експлуатації. Отримані результати дозволяють прогнозувати інтервали експлуатаційних і відновлювальних заходів, виділяючи найбільш проблемні елементи системи.

Ключові слова: ймовірність безвідмовної роботи, параметр потоку відмов, структурна модель, елемент, система

V. Kovalchuk, I. Kozlov, O. Dorozh, O. Siedova. Assessment of the reliability of the NPP liquid radioactive waste concentration system. The calculation of the reliability indicators of the system for the concentration of liquid radioactive waste at a nuclear power plant. The special wastewater treatment (NWT-3) of units with VVER reactors was adopted as a basic scheme. The aim of the work is to estimate the reliability of NWT -3 as a technological system. The goal is achieved by transforming the technological scheme of the system into a structural one and determining the quantitative values of the parameter of the flow of failures, the duration and probability of failure-free operation. A structural model of the system was built taking into account redundancy and suspended elements. The characteristic ways of connecting elements in the system are considered: sequential, one- and two-fold permanent redundancy, under the same loading conditions of the main and reserve elements and performing the same functions. Data on the parameters of the failure flow of the equipment that makes up the technological scheme are borrowed from reference sources. Communication means present in the diagram (valves, flanges, pipelines, etc.) are taken into account as connected serial elements of the main equipment. The probabilities of failure-free operation of equipment are calculated and the most problematic ones are identified: pumps, evaporators and heat exchangers. The probabilities of failure-free operation of the system as a whole are determined for a number of specified intervals of operation as the corresponding products of the probability of failure-free operation of the elements that make up the system. It is shown that if the parameter of the flow of failures remains unchanged, the probability of failure-free operation of the system, ensuring its effective functioning, will remain within one year of operation. The results obtained allow predicting the intervals of operational and recovery measures, highlighting the most problematic elements of the system.

Keywords: probability of failure-free operation, parameter of the flow of failures, structural model, element, system
\end{abstract}

\section{Introduction}

Nuclear energy in Ukraine is an important component of the overall fuel and energy complex and takes a leading position in the country's electricity supply [1].

The main modern directions for the development of nuclear power are associated with increasing the reliability of systems and equipment, which are priority for safe operation. Nuclear energy is characterized by specific factors associated with radioactivity and the radiological consequences of its im-

\section{DOI: 10.15276/opu.3.62.2020.06}

(C) 2020 The Authors. This is an open access article under the CC BY license (http://creativecommons.org/licenses/by/4.0/). 
pact on humans and the environment. During the operation of a nuclear power plant in normal modes, liquid, solid and gaseous radioactive waste is generated [2].

Strategies for handling radioactive waste of all categories are based on the principle of preventing negative impacts on humans and the environment. The bulk of the waste is made up of liquid coolants of varying saturation with radionuclides. The ultimate goal of handling them is to concentrate them to a state suitable for subsequent implementation in solid matrices.

The concentration process is carried out in several stages sequentially using separation technologies by mechanical, chemical, thermal and electrical methods. Continuous waste generation is accompanied by the same processing regime.

To implement these processes, equipment sequences are formed, which, after some time intervals, lose their ability to perform their functions, that is, a so-called "failure" occurs - a violation of the system's performance. Therefore, predicting the reliability of the functioning of the equipment that makes up such sequences seems to be very relevant.

\section{Analysis of recent publications}

Concentration of liquid radioactive waste (LRW) at NPPs with water-water power reactor (WWPR) is carried out by special water treatment system NWT-3, which is a set of interconnected technological streams and apparatuses acting as a whole, in which a certain sequence of technological operations is carried out and corresponds to the definition of the concept of "technological system" (Fig. 1) [3, 4].

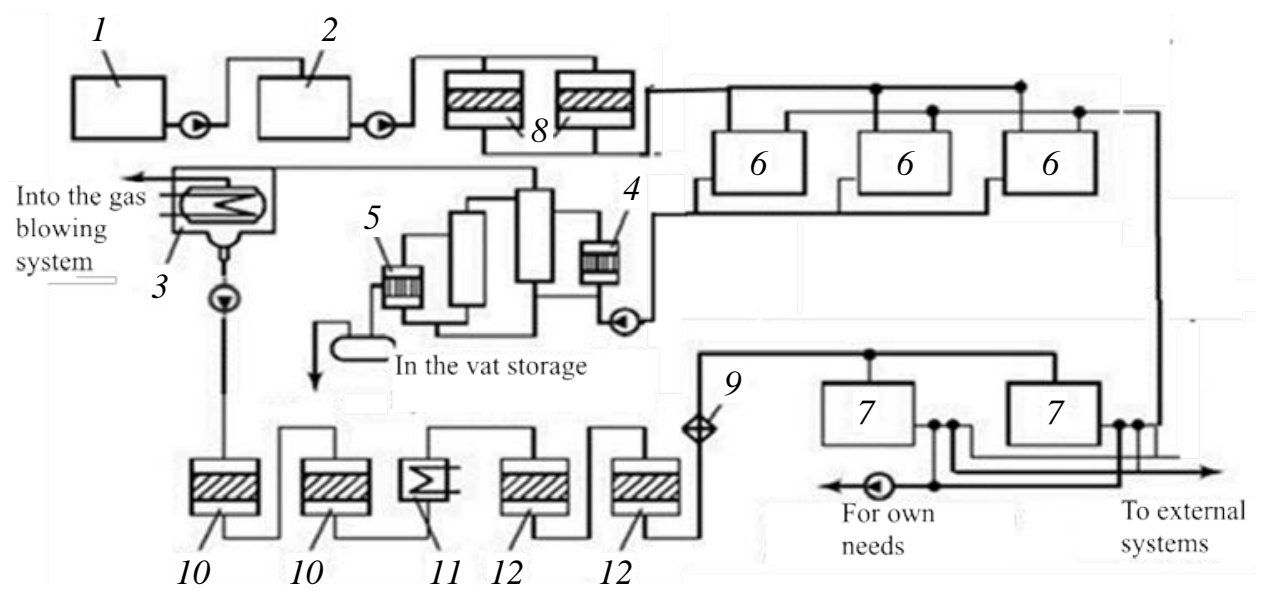

Fig. 1. System NWT-3: 1 - special sewerage tank; 2 - settling tank; 3 - condenser-degasser; 4 - evaporator; 5 - additional steamer; 6 - trap water tanks; 7 - control tanks; 8 - mechanical filters; 9 - trap filter; 10 - carbon filters; 11 - cooler; 12 - ion exchange filters

In the general structure of NPP the special water treatment facilities is a technological object, i.e. a part of a technological system containing a group of devices united geographically and connected by technological flows, in which a set of physic and chemical or physic and mechanical transformations of substances and a change in the values of parameters of material media are realized.

As a technological object, NWT-3 is connected with the following technological objects of the system: water purification of the fuel pool; industrial cooling circuit of consumers; LRW solidification; intermediate storage of used sorbents; water for own needs; collection of unorganized leakage of the containment; collection of drainage; a couple of their own needs; gas blowing; collection and return of condensate; purification of blowdown water of steam generators; compressed air; preparation of chemical reagents.

The NWT-3 unit uses the methods of evaporation, degassing, mechanical filtration and ion exchange.

NPP designs envisage one working evaporator for two power units with WWPR-1000 reactors. The distillation residue is sent to the vessel and further for additional evaporation or maturation.

Purpose and objectives of the study

The ramified connection of NWT-3 with technological facilities of the LRW management system suggests its significant contribution to the reliability and safety of the NPP. The purpose of the pre- 
sented material is to estimate the reliability of the NWT-3 system as a technological system. To achieve this goal, it is necessary to solve problems:

- transformation of the technological scheme into a structural one, taking into account duplication and redundancy of elements;

- determination of quantitative values of the parameter of the flow of failures, duration and probability of failure-free operation.

Reliability analysis is carried out at various stages of the object's life cycle: during design, manufacture, testing, installation, start-up, operation, etc. Based on the results of calculating the reliability characteristics, as well as their changes over time, the following decisions are made: about the need to change or refine technological schemes, on the need to improve reliability, on the possibility of putting an object into production or discontinuing production, on setting a schedule for preventive maintenance and repairs or changing it, on the required nomenclature and quantity of spare parts, assemblies and parts, on the possibility of further operation, on modernization, about write-off, etc.

\section{Research methods for the reliability of technological systems}

The reliability of a technological system is determined, on the one hand, by the absence of failures (failures and errors in operation) of its constituent devices, on the other hand, by the possibility of restoring them to an operable state. It is estimated by dimensional (average recovery time of an element) or dimensionless (probability of failure-free operation of an element, system) reliability indicators.

The system under consideration is built of serviceable recoverable elements of long-term operation. The indicators of their reliability include:

- parameter of the flow of failures,

$$
\omega(t)=n(\Delta t) /(N \cdot \Delta t),
$$

where $n(\Delta t)$ - the number of failed samples in the time interval from $t-\Delta t / 2$ to $t+\Delta t / 2$;

$N$ is the number of tested samples;

$\Delta t$ is the time interval;

- mean time between failures - average value of time between adjacent failures,

$$
t_{\mathrm{av}}=\left(\sum_{i=1}^{n} t_{i}\right) / n
$$

where $t_{i}$ is the time of correct operation of the product between the (i-1)-th and $i$-th failures;

$n$ is the number of failures for some time $t$;

- probability of failure-free operation - the probability that within a given operating time or a given time interval, an object's failure does not occur;

- availability factor.

The analysis of the reliability of the technological system should be performed step by step (Fig. 2) [5].

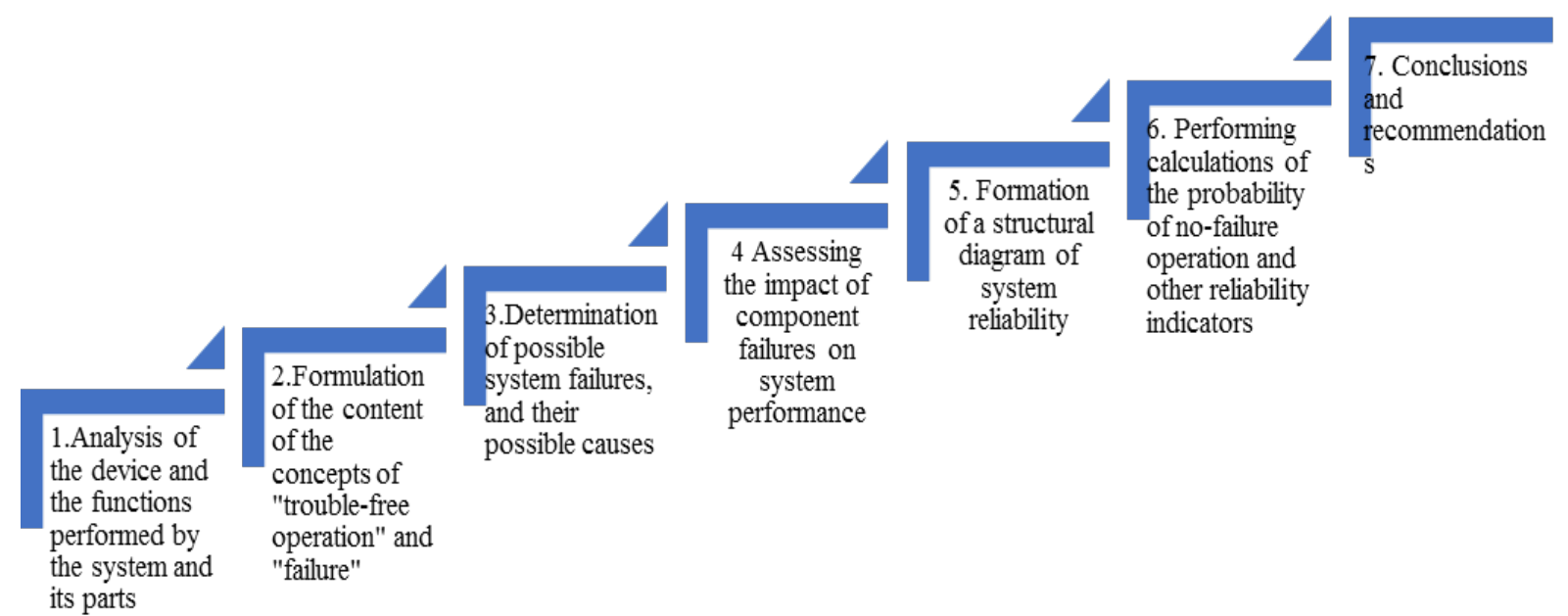

Fig. 2. The sequence of the analysis of the reliability of the technological system 


\section{Calculated assessment of the structural reliability of the system}

To perform calculations, the technological scheme (Fig. 1) of the system was transformed into a structural one with indication of the values of the parameter of the flow of failures [6]. The structural diagram compiled according to the results of the analysis of the reliability of the technological system (Fig. 2) is supplemented with fittings and pipelines for communication, which are connected in series with the corresponding elements of the diagram (Table 1).

Table 1

Structural diagram of the NWT-3 reliability and types of failures

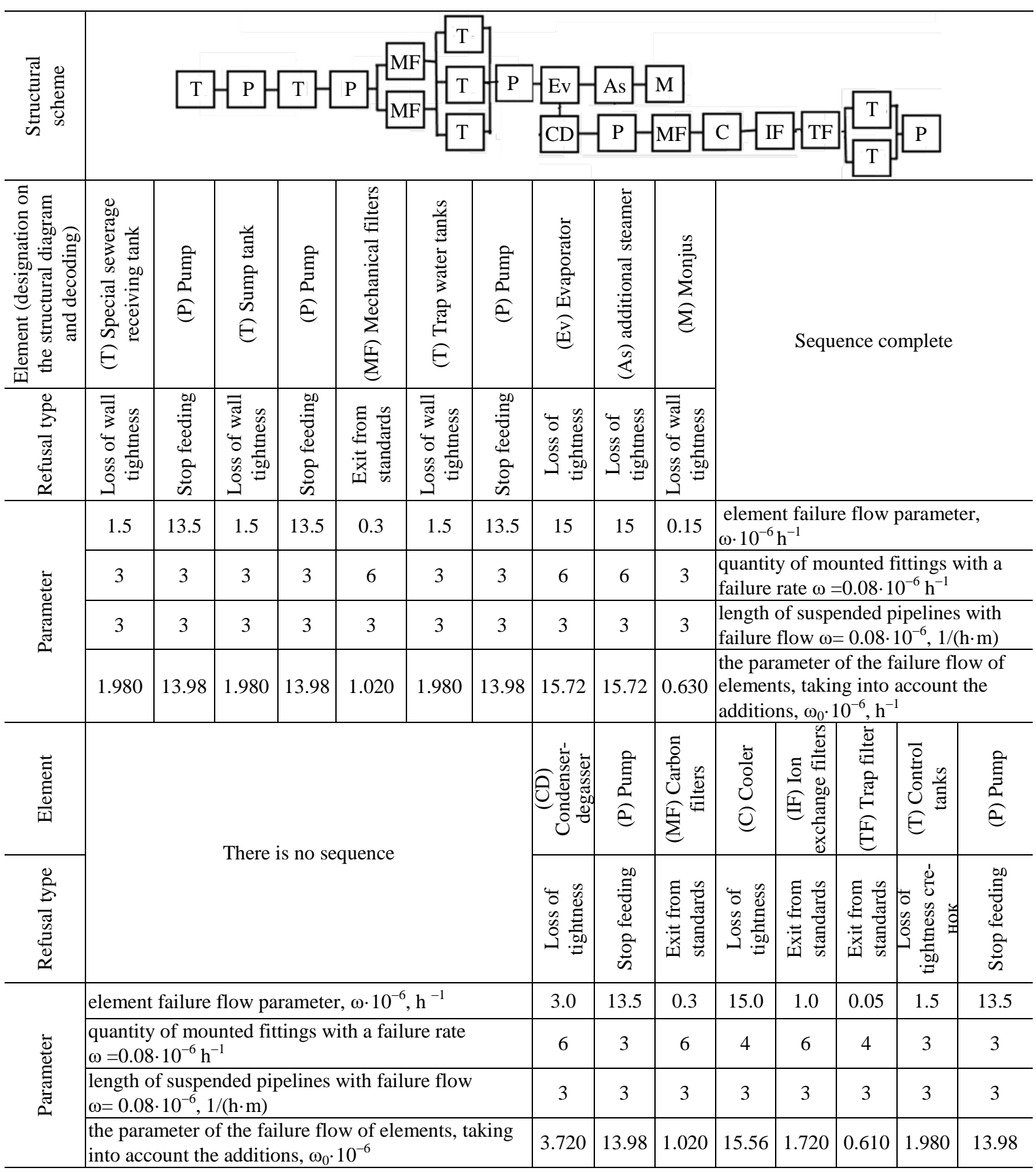


When calculating the reliability of a system with a serial connection, the probability of the joint occurrence of independent events $P(t)$ is equal to the product of the probabilities pi $(t)$ and is represented as the product of the probabilities of the failure-free operation of the elements (Table 2):

$$
P(t)=p_{1}(t) \times p_{2}(t) \times \ldots \times p_{n}(t)=\prod_{i=1}^{n} p_{i}(t) .
$$

The parameter of the flow of failures and the probability of failure-free operation are interconnected by the dependence [7]:

$$
P(t)=e^{-\int_{0}^{i} \omega(t) d t} \text { or } P\left(T_{0}\right)=\exp \left(-\omega_{i} \cdot T_{0}\right),
$$

where $\omega_{i}$ - failure flow parameter for recoverable elements;

$T_{0}$ - estimated period of time of work.

Table 2

\begin{tabular}{|c|c|c|c|c|c|c|c|c|c|c|c|}
\hline \multirow[b]{2}{*}{ № } & \multirow[b]{2}{*}{ Element } & \multicolumn{2}{|c|}{ Element } & \multicolumn{3}{|c|}{ Armature } & \multicolumn{3}{|c|}{ Pipelines } & \multicolumn{2}{|c|}{ United } \\
\hline & & $\begin{array}{l}\omega \cdot 10^{-6}, \\
\text { hour }^{-1}\end{array}$ & $p_{i}(t)$ & \begin{tabular}{|c|} 
quantity, \\
pcs.
\end{tabular} & $\begin{array}{l}\omega \cdot 10^{-8}, \\
\text { hour }^{-1}\end{array}$ & $p_{i}(t)$ & length, $\mathrm{m}$ & $\begin{array}{c}\omega \cdot 10^{-8}, \\
1 / \text { (hour m) }\end{array}$ & $p_{i}(t)$ & $P_{u i}(t)$ & $\begin{array}{c}\omega_{u i}: 10^{-6}, \\
\text { hour }^{-1}\end{array}$ \\
\hline 1 & $\begin{array}{l}\text { Special sewerage } \\
\text { tank }\end{array}$ & 1.50 & 0.9876 & 3 & 8.00 & 0.9980 & 3 & 8.00 & 0.9980 & 0.9837 & 1.98 \\
\hline 2 & Pump & 13.5 & 0.8940 & 3 & 8.00 & 0.9980 & 3 & 8.00 & 0.9980 & 0.8904 & 13.98 \\
\hline 3 & Sump tank & 1.50 & 0.9876 & 3 & 8.00 & 0.9980 & 3 & 8.00 & 0.9980 & 0.9837 & 1.98 \\
\hline 4 & Pump & 13.5 & 0.8940 & 3 & 8.00 & 0.9980 & 3 & 8.00 & 0.9980 & 0.8904 & 13.98 \\
\hline 5 & Mechanical filters & 0.30 & 0.9975 & 6 & 8.00 & 0.9960 & 3 & 8.00 & 0.9980 & 0.9916 & 1.02 \\
\hline 6 & Trap water tanks & 1.50 & 0.9876 & 3 & 8.00 & 0.9980 & 3 & 8.00 & 0.9980 & 0.9837 & 1.98 \\
\hline 7 & Pump & 13.5 & 0.8940 & 3 & 8.00 & 0.9980 & 3 & 8.00 & 0.9980 & 0.8904 & 13.98 \\
\hline 8 & Evaporator & 15.0 & 0.8829 & 6 & 8.00 & 0.9960 & 3 & 8.00 & 0.9980 & 0.8777 & 15.72 \\
\hline 9 & Additional steamer & 15.0 & 0.8829 & 6 & 8.00 & 0.9960 & 3 & 8.00 & 0.9980 & 0.8777 & 15.72 \\
\hline 10 & Monjus & 0.15 & 0.9988 & 3 & 8.00 & 0.9980 & 3 & 8.00 & 0.9980 & 0.9948 & 0.63 \\
\hline 11 & $\begin{array}{l}\text { Condenser- } \\
\text { degasser }\end{array}$ & 3.00 & 0.9754 & 6 & 8.00 & 0.9960 & 3 & 8.00 & 0.9980 & 0.9696 & 3.72 \\
\hline 12 & Pump & 13.5 & 0.8940 & 3 & 8.00 & 0.9980 & 3 & 8.00 & 0.9980 & 0.8904 & 13.98 \\
\hline 13 & Carbon filters & 0.30 & 0.9975 & 6 & 8.00 & 0.9960 & 3 & 8.00 & 0.9980 & 0.9916 & 1.02 \\
\hline 14 & Cooler & 15.0 & 0.8829 & 4 & 8.00 & 0.9973 & 3 & 8.00 & 0.9980 & 0.8788 & 15.56 \\
\hline 15 & $\begin{array}{c}\text { Ion exchange fil- } \\
\text { ters }\end{array}$ & 1.00 & 0.9917 & 6 & 8.00 & 0.9960 & 3 & 8.00 & 0.9980 & 0.9858 & 1.720 \\
\hline 16 & Trap filter & 0.05 & 0.9996 & 4 & 8.00 & 0.9973 & 3 & 8.00 & 0.9980 & 0.9949 & 0.61 \\
\hline 17 & Control tanks & 1.50 & 0.9876 & 3 & 8.00 & 0.9980 & 3 & 8.00 & 0.9980 & 0.9837 & 1.98 \\
\hline 18 & Pump & 13.5 & 0.8940 & 3 & 8.00 & 0.9980 & 3 & 8.00 & 0.9980 & 0.8904 & 13.98 \\
\hline
\end{tabular}

Changes in the flow of failures and the likelihood of no-failure operation of equipment with attached elements

Items 5, 6 and 17 are double and triple redundant, which should increase the likelihood of system uptime.

For a system with parallel connection of elements to fail during the operating time $t$, it is necessary and sufficient that all its elements fail during this operating time [7]. If the failures of the elements are independent of each other, then, according to the probability multiplication theorem, the probability of system failure $Q$ is equal to the product of the failure probabilities $q_{i}$ (or the product of the differences 1 and the probabilities of failure-free operation $p_{i}$ ) of its elements (Table 3):

$$
Q=\prod_{i=1}^{n} q_{i}=\prod_{i=1}^{n}\left(1-p_{i}\right)
$$

that is, for a parallel connection, the probabilities of failure of non-recoverable elements are multiplied. 
Accordingly, the probability of no-failure operation for time $t$ is equal to:

$$
P=1-Q=1-\prod_{i=1}^{n} q_{i}=1-\prod_{i=1}^{n}\left(1-p_{i}\right),
$$

where $p_{i}$ - reliability function of the $i$-th element of the system.

If the system consists of equally reliable elements $(p i=p)$, then:

$$
Q=q^{n}, \quad P=1-(1-p)^{n} .
$$

Table 3

Change in the flow of failures and the likelihood of equipment uptime by redundant elements

\begin{tabular}{c|l|c|c|c|c}
\hline \multirow{2}{*}{$№$} & \multirow{2}{*}{ Element } & Unit probability & Failure flow parameter & $\begin{array}{c}\text { Number of } \\
\text { elements }\end{array}$ & \multirow{2}{*}{$\begin{array}{c}\text { General } \\
\text { probability }\end{array}$} \\
\cline { 3 - 5 } & & $P_{\text {ui }}(t)$ & $\omega_{\boldsymbol{u}} \cdot 10^{-6}$, hour $^{-1}$ & pcs. & \\
\hline 1 & Mechanical filters & 0.9916 & $1.020 \mathrm{E}-06$ & 2 & 0.999929 \\
\hline 2 & Trap water tanks & 0.9837 & $1.980 \mathrm{E}-06$ & 3 & 0.999996 \\
\hline 3 & Control tanks & 0.9837 & $1.980 \mathrm{E}-06$ & 2 & 0.999734 \\
\hline
\end{tabular}

According to the results of the transformation of the technological scheme into a structural one, taking into account the connected elements and redundancy of the apparatus, it can be seen that the least reliable are pumps, evaporators and heat exchangers (Fig. 3).

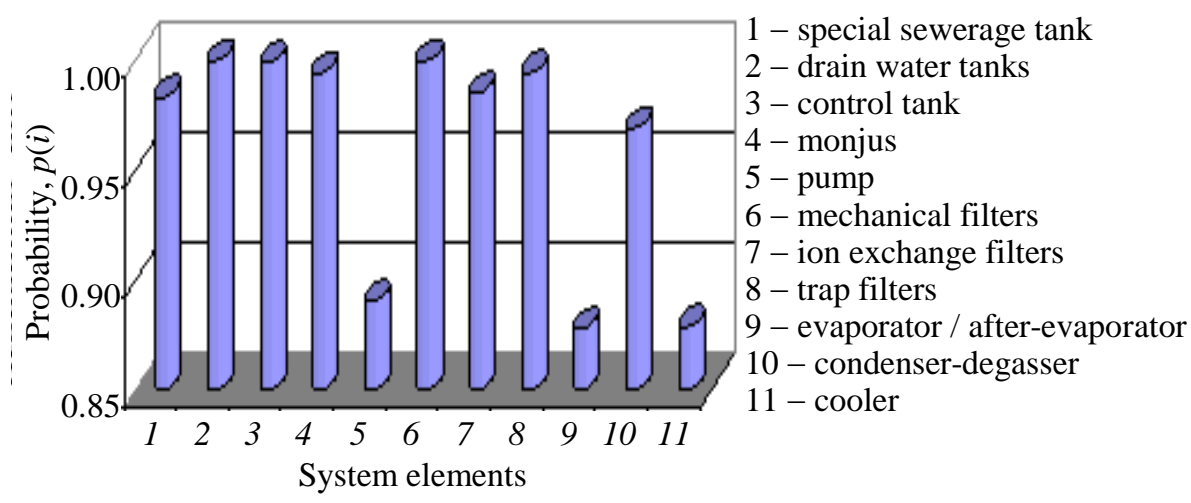

Fig. 3. Probabilities of failure-free operation of the elements of the NWT-3 system

The resulting structural model of NWT-3 is a serial connection of elements. To assess its probability of no-failure operation, it is sufficient, in accordance with expression (3), to multiply the data in column 11 of Table 2. Having performed these calculations for a number of specified operating time intervals, we obtain the dependence of the probability of no-failure operation on the duration of operation (Fig. 4).

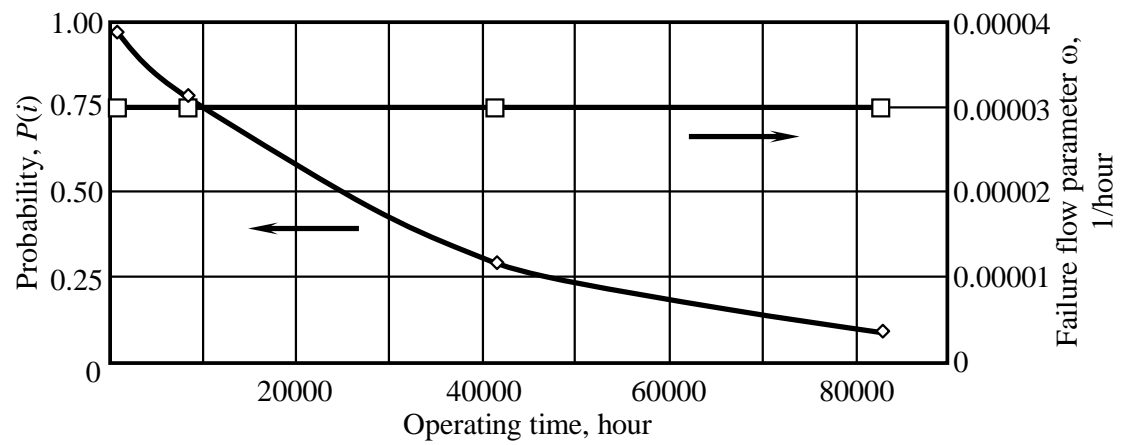

Fig. 4. Probability of failure-free operation of the NWT-3 system 
The resulting dependence of the probability of no-failure operation on time is approximated by an exponential function:

$$
P(t)=\exp \left(-3 \cdot 10^{-5} \cdot t\right)
$$

where $t$ is the system operating time, hours.

In this case, the parameter of the flow of failures remains unchanged.

\section{Conclusions}

1. The conversion of the technological scheme of the liquid radioactive waste concentration system into a structural-logical model that allows assesses the reliability of the system is proposed.

2. The types of failures of elements of the structural model and the numerical values of their parameters of failure flows have been determined.

3. The calculation of the reliability of the functional part of the system is presented, the elements for which the highest values of flows are characteristic, taking into account constantly attached elements, are highlighted.

4. It is shown that if the parameter of the flow of failures remains unchanged, the probability of failure-free operation of the system, ensuring its efficient operation, will remain within one year of operation.

5. The obtained results make it possible to predict the intervals of operational and restoration measures, highlighting the most problematic elements of the system.

\section{Література}

1. Публічні обговорення питань реалізації Комплексної зведеної програми (КЗПБ) // Інформаційний вісник «Енергетик». 2020. № 43(1849). С. 4. URL: https://www.sunpp.mk.ua/ uk/info/ info_production/energetik/1849.

2. Ключников А.А., Пазухин Э.М., Шигера Ю.М., Шигера В.Ю. Радиоактивные отходы АЭС и методы обращения с ними. Киев : Институт проблем безопасности АЭС НАН Украины, 2005. 487 с.

3. Общие правила взрывобезопасности для взрывопожароопасных химических, нефтехимических и нефтеперерабатывающих производств (ПБ 09-170-97). 1997. 47 c. URL: https://files.stroyinf.ru/ Data1/5/5957/index.htm.

4. Оптимизация плановых ремонтов энергоблоков атомных электростанций с ВВЭР : монография / В.И. Скалозубов, Ю.Л. Коврижкин, В.Н. Колыханов и др. / под ред. В.И. Скалозубова. Чернобыль : Ин-т проблем безопасности АЭС, 2008. 496 с.

5. Е.В. Сугак, Н.В. Василенко, Г.Г. Назаров, А.Б. Паньшин, А.П. Каркарин Надежность технических систем. Учеб. пособие для технических специальностей вузов. / Е.В. Сугак, Н.В. Василенко, Г.Г. Назаров, А.Б. Паньшин, А.П. Каркарин. / под общ. ред. Е.В. Сугака и Н.В. Василенко. Красноярск : НИИ СУВПТ, МГП «Раско», 2001. 608 с.

6. Denson W., Chandler G., Crowell W., Wanner R. Nonelectronic parts reliability. IIT Research Institute, Reliability Analysis Center. Rome : NY, 1991. 632 p. URL: https://apps.dtic.mil/dtic/ tr/fulltext/u2/a242083.pdf.

7. Гнеденко Б.В., Беляев Ю.К., Соловьев А.Д. Математические методы в теории надежности: Основные характеристики надежности и их статистический анализ. M. : URSS, 2013. 584 с.

\section{References}

1. Publication of nutritional support for the implementation of the Integrated Manufactured Programs (KZPB). (2020). Information Bulletin “Energetik", 43(1849). Retrieved from: https://www.sunpp. mk.ua/ uk/info/ info_production/energetik/1849.

2. Klyuchnikov, A.A., Pazukhin, E.M, Shiger, Yu.M., \& Shiger, V.Yu. (2005). Nuclear power plant radioactive waste and methods of handling them. Kyiv: Institute for NPP Safety Problems of the National Academy of Sciences of Ukraine.

3. General rules of explosion safety for explosion and fire hazardous chemical, petrochemical and oil refining industries (PB 09-170-97). (1997). 47 p. Retrieved from: https:/files.stroyinf.ru/Data1/ 5/5957/index.htm. 
4. Skalozubov, V.I., Kovrizhkin, Yu.L., \& Kolykhanov, V.N. et al. (2008). Optimization of planned repairs of power units of nuclear power plants with VVER: monograph. V.I. Skalozubov (Ed.). Chernobyl: Institute of NPP safety problems.

5. Sugak, E.V., Vasilenko, N.V., Nazarov, G.G., Panshin, A.B., \& Karkarin, A.P. (2001). Reliability of technical systems. Textbook manual for technical specialties of universities. E.V. Sugaka and N.V. Vasilenko (Eds.). Krasnoyarsk: NII SUVPT, MGP “Rasko".

6. Denson, W., Chandler, G., Crowell, W., \& Wanner, R. (1991). Nonelectronic parts reliability. IIT Research Institute, Reliability Analysis Center, Rome: NY. Retrieved from: https://apps.dtic.mil/ dtic/tr/fulltext/u2/a242083.pdf.

7. Gnedenko, B.V., Belyaev, Yu.K., \& Soloviev, A.D. (2013). Mathematical methods in the theory of reliability: Basic characteristics of reliability and their statistical analysis. M.: URSS.

Ковальчук В'ячеслав Іванович; Kovalchuk Vyacheslav, ORCID: https://orcid.org/0000-0001-8696-4414

Козлов Ігор Леонідович; Kozlov Igor, ORCID: http://orcid.org/0000-0003-0435-6373

Дорож Ольга Анатоліївна; Dorozh Olga, ORCID: https://orcid.org/0000-0001-8495-2911

Сєдова Ольга Олександрівна; Siedova Olga, ORCID: : https://orcid.org/0000-0003-1671-4369

Received August 25, 2020

Accepted November 13, 2020 